\title{
Digitoxigenin presents an effective and selective antileishmanial action against Leishmania infantum and is a potential therapeutic agent for visceral leishmaniasis
}

\author{
Camila S. Freitas ${ }^{1}$ • João A. Oliveira-da-Silva ${ }^{1}$. Daniela P. Lage ${ }^{1} \cdot$ Rafaella R. Costa ${ }^{1}$ - Débora V. C. Mendonça ${ }^{1}$. \\ Vívian T. Martins ${ }^{1} \cdot$ Thiago A. R. Reis ${ }^{1} \cdot$ Luciana M. R. Antinarelli $^{2} \cdot$ Amanda S. Machado $^{1} \cdot$ Grasiele S. V. Tavares $^{1}$. \\ Fernanda F. Ramos ${ }^{1}$ • Vinicio T. S. Coelho ${ }^{1} \cdot$ Rory C. F. Brito ${ }^{3} \cdot$ Fernanda Ludolf $^{1}$ • Miguel A. Chávez-Fumagalli ${ }^{4}$. \\ Bruno M. Roatt ${ }^{3}$. Gabriela S. Ramos ${ }^{5}$. Jennifer Munkert ${ }^{6}$. Flaviano M. Ottoni ${ }^{5}$ - Priscilla R. V. Campana ${ }^{5}$. \\ Maria V. Humbert ${ }^{7}$. Elaine S. Coimbra ${ }^{2}$ - Fernão C. Braga ${ }^{5} \cdot$ Rodrigo M. Pádua $^{5}$ • Eduardo A. F. Coelho ${ }^{1,8} \mathbb{C}$
}

Received: 20 August 2020 / Accepted: 5 November 2020 / Published online: 16 November 2020

(C) Springer-Verlag GmbH Germany, part of Springer Nature 2020

\begin{abstract}
Treatment for visceral leishmaniasis (VL) is hampered mainly by drug toxicity, their high cost, and parasite resistance. Drug development is a long and pricey process, and therefore, drug repositioning may be an alternative worth pursuing. Cardenolides are used to treat cardiac diseases, especially those obtained from Digitalis species. In the present study, cardenolide digitoxigenin (DIGI) obtained from a methanolic extract of Digitalis lanata leaves was tested for its antileishmanial activity against Leishmania infantum species. Results showed that $50 \%$ Leishmania and murine macrophage inhibitory concentrations $\left(\mathrm{IC}_{50}\right.$ and $\mathrm{CC}_{50}$, respectively) were of $6.9 \pm 1.5$ and $295.3 \pm 14.5 \mu \mathrm{g} / \mathrm{mL}$, respectively. With amphotericin B (AmpB) deoxycholate, used as a control drug, values of $0.13 \pm 0.02$ and $0.79 \pm 0.12 \mu \mathrm{g} / \mathrm{mL}$, respectively, were observed. Selectivity index (SI) values were of 42.8 and 6.1 for DIGI and AmpB, respectively. Preliminary studies suggested that the mechanism of action for DIGI is to cause alterations in the mitochondrial membrane potential, to increase the levels of reactive oxygen species and induce accumulation of lipid bodies in the parasites. DIGI was incorporated into Pluronic $®$ F127-based polymeric micelles, and the formula (DIGI/Mic) was used to treat $L$. infantum-infected mice. Miltefosine was used as a control drug. Results showed that animals treated with either miltefosine, DIGI, or DIGI/Mic presented significant reductions in the parasite load in their spleens, livers, bone marrows, and draining lymph nodes, as well as the development of a specific Th1-type response, when compared with the controls. Results obtained 1 day after treatment were corroborated with data corresponding to 15 days after therapy. Importantly, treatment with DIGI/Mic induced better parasitological and immunological responses when compared with miltefosine- and DIGI-treated mice. In conclusion, DIGI/Mic has the potential to be used as a therapeutic agent to protect against $L$. infantum infection, and it is therefore worth of consideration in future studies addressing VL treatment.
\end{abstract}

Keywords Treatment $\cdot$ Digitoxigenin $\cdot$ Drug repositioning $\cdot$ Visceral leishmaniasis $\cdot$ Amphotericin B deoxycholate $\cdot$ Miltefosine

\section{Introduction}

Leishmaniases are protozoal vector-borne diseases that affect both humans and animals. There are approximately 380 million people at risk of contracting infection and 2.0 million

Section Editor: Sarah Hendrickx

Eduardo A. F. Coelho

eduardoferrazcoelho@yahoo.com.br

Extended author information available on the last page of the article cases registered annually (WHO 2018). This disease complex is caused by some species of the Leishmania genus, being the tegumentary and visceral leishmaniases, the main clinical forms of the disease (Grimaldi and Tesh 1993). Visceral leishmaniasis (VL) is a worldwide-distributed infectious disease that, when symptomatic, causes fever, hepatosplenomegaly, and pancytopenia, among others (Burza et al. 2018). Its diagnosis is accomplished by molecular and/or conventional parasitological techniques, as well as by immunological assays. However, accurate diagnosis depends on the current clinical status and immune response of the infected hosts, with falsenegative and/or false-positive results being frequently 
encountered (Sakkas et al. 2016; Jamal et al. 2017; Van Griensven and Diro 2019).

VL treatment has long relied on the use of pentavalent antimonials. However, long periods of parenteral administration cause toxicity to the patients, who present with symptoms such as cardiac arrhythmias, prolonged QT interval, ventricular premature beats, ventricular tachycardia, and fibrillation (Sundar and Chakravarty 2015). In addition, parasite resistance has been reported, limiting their effectiveness as clinical antileishmanial drugs (Sundar and Singh 2018). Other therapeutic agents are also available and are currently being employed to treat VL. Despite presenting high efficacy, toxicity and/or high costs are also limitations for their widespread use within a clinical setting (Chakravarty and Sundar 2019). Amphotericin B (AmpB) deoxycholate is one of these alternative drugs, which toxic effects include nephrotoxicity, hypokalemia, and myocarditis (Mohamed-Ahmed et al. 2012). AmpB-containing lipid formulations were developed with the aim to reduce side effects. Besides their low toxicity, these formulations have shown to induce high therapeutic responses, but their high cost is still a limiting factor (Sundar et al. 2019). Miltefosine was originally used as an antitumor agent, and its leishmanicidal potential was reported in the 1980s (Dorlo et al. 2012). It was the first drug used to treat VL via oral administration. Miltefosine inhibits the biosynthesis of the glycosyl phosphatidyl inositol receptor, a key molecule for Leishmania intracellular survival. Unfortunately, miltefosine is teratogenic, and parasite resistance has been also registered (Rijal et al. 2013; Srivastava et al. 2017).

In this context, there is currently an urgent need to identify novel effective, non-toxic, low-cost antileishmanial agents. Drug discovery is a long and expensive process, and leishmaniasis is a neglected disease (Hughes et al. 2011). Thus, drug repositioning may well represent an attractive alternative, since compounds with known biological functions have been proved to be effective against parasites (Andrade-Neto et al. 2018). Cardenolides are glycosides able to inhibit $\mathrm{Na}^{+} / \mathrm{K}^{+}$ATPases by obstructing the $\mathrm{Na}^{+} / \mathrm{K}^{+}$pump mechanism (Mijatovic and Kiss 2013; Patel et al. 2019). These compounds are clinically used to treat cardiac diseases, such as congestive heart failure (Gheorghiade et al. 2009), and they have been reported also to possess antitumor (Slingerland et al. 2013), antimalarial (Chan et al. 2016), and antioxidant (Xu et al. 2017) activities, among others (Eid et al. 2012; Gurel et al. 2017). In the present study, a cardenolide derivate called digitoxigenin (DIGI) was obtained from a methanolic extract of Digitalis lanata leaves, and its antileishmanial activity was evaluated against $L$. infantum species.

Experimental results showed that DIGI was effective against parasites, presenting a higher selectivity index (SI) than $\mathrm{AmpB}$, with corresponding high efficacy in the treatment of infected murine macrophages. Preliminary studies showed that DIGI induced alterations in the parasite mitochondrial membrane potential $(\Delta \Psi \mathrm{m})$ and stimulated the production of reactive oxygen species (ROS) and the accumulation of lipid bodies in the parasites. Furthermore, studies in vivo showed that DIGI administered either in a free format or incorporated into poloxamer 407-based polymeric micelle system (DIGI/Mic) significantly reduced the parasite load in the spleens, livers, bone marrows (BM), and draining lymph nodes (dLNs) of $L$. infantum-infected mice, 1 and 15 days post-treatment. Immunological data demonstrated that both DIGI and DIGI/Mic stimulated also the development of an antileishmanial Th1-type cellular and humoral immune response 1 and 15 days after treatment, suggesting the potential of this cardenolide derivate as an effective alternative therapeutic agent against VL.

\section{Materials and methods}

\section{Ethics statement, experimental animals, and chemicals}

The study was approved by the Committee for the Ethical Handling of Research Animals of Federal University of Minas Gerais (UFMG; Belo Horizonte, Minas Gerais, Brazil), with protocol number 085/2017. BALB/c mice (female, 8 weeks old) were purchased from the Institute of Biological Sciences of UFMG, and they were kept under pathogen-free conditions. Poloxamer 407 (Pluronic $®$ F127), miltefosine, and AmpB were acquired from Sigma-Aldrich (catalog numbers 16758, 58066-85-6, and 1397-89-3, respectively; St. Louis, USA).

\section{Extraction and purification of DIGI}

DIGI was obtained according to the method reported by Pádua et al. (2005), with few modifications. Briefly, a methanolic extract from Digitalis lanata leaves (kindly donated by Prof. Wolfgang Kreis, University of Erlangen-Nuremberg, Germany), which is an industrial refuse resulting from the extraction of digoxin, was resuspended $(17 \mathrm{~g})$ in $200 \mathrm{~mL}$ acetone and sonicated for $30 \mathrm{~min}$ at room temperature. The acetonic extract obtained was filtrated through a sintered Büchner funnel (no. 1-100- to $160-\mu \mathrm{m}$ pore sizes), and the process was repeated with the insoluble material using $100 \mathrm{~mL}$ acetone. The acetone extract was filtered over $30 \mathrm{~g}$ of activated charcoal powder under reduced pressure to remove chlorophyll and other pigments. The active charcoal was washed with acetone $(100 \mathrm{~mL})$, and the filtrate was evaporated to dryness to allow the dry extract to enrich in cardenolides (10 g). The dry extract was dissolved in $400 \mathrm{~mL}$ methanol and stirred on an oil bath until the temperature reached $55^{\circ} \mathrm{C}$. Then, $350 \mathrm{~mL} 1 \mathrm{M}$ hydrochloric acid was added, and the solution was stirred for $35 \mathrm{~min}$ at room temperature. Next, it was partitioned with dichloromethane $(3 \times 200 \mathrm{~mL})$, 
and the organic layer was neutralized by partition with $50 \mathrm{~mL} 3 \%$ (w/v) $\mathrm{NaHCO}_{3}$ aqueous solution. The organic layer was then washed with water $(3 \times 100 \mathrm{~mL})$ and dried over anhydrous sodium sulfate, and dichloromethane was evaporated to dryness to get the dried residue $(7.0 \mathrm{~g})$, which was dissolved in dichloromethane $(100 \mathrm{~mL})$ and filtered under reduced pressure over silica gel $(50.0 \mathrm{~g} ; 0.04-0.063 \mathrm{~mm})$ deposited in a sintered Buchner funnel (no. 4-10- to $16-\mu \mathrm{m}$ pore sizes). The silica gel was sequentially washed using mixtures of dichloromethane (A) and ethyl acetate (B): $100 \% \mathrm{~A}(100 \mathrm{~mL}), 95 \% \mathrm{~A} / 5 \% \mathrm{~B}(950 \mathrm{~mL})$, $90 \% \mathrm{~A} / 10 \% \mathrm{~B}(750 \mathrm{~mL})$, and $70 \% \mathrm{~A} / 30 \% \mathrm{~B}(250 \mathrm{~mL})$. Fortyone fractions were collected $(50 \mathrm{~mL}$ each); the solvent was removed in a fume hood for $18 \mathrm{~h}$ at room temperature, and fractions were submitted to thin-layer chromatography analysis over silica gel (eluent: ethyl acetate; spray reagent: Kedde). Fractions containing DIGI (fractions 25 to 34) were pooled and used to purify the molecule (1.4 g; purity $>98 \%$; Fig. 1).

\section{Parasites}

L. infantum (MHOM/BR/1970/BH46) parasites were grown at a $24{ }^{\circ} \mathrm{C}$ in complete Schneider's medium (Sigma-Aldrich, USA), supplemented with $20 \%(\mathrm{v} / \mathrm{v})$ heat-inactivated fetal bovine serum (FBS; Sigma-Aldrich, USA) and $20 \mathrm{mM} \mathrm{L-glu-}$ tamine pH 7.4 (Coelho et al. 2003).

\section{Antileishmanial activity}

Fifty percent of $L$. infantum inhibitory concentration $\left(\mathrm{IC}_{50}\right)$ was evaluated by incubating parasite stationary promastigotes ( $10^{6}$ cells) with DIGI (0 to $50.0 \mu \mathrm{g} / \mathrm{mL}$ ) or AmpB (0 to 10.0 $\mu \mathrm{g} / \mathrm{mL}$; Sigma-Aldrich, USA) in 96-well culture plates (Nunc, Nunclon, Roskilde, Denmark) for $48 \mathrm{~h}$ at $24^{\circ} \mathrm{C}$. Cell viability was assessed using the 3-(4.5-dimethylthiazol-2-yl)-2.5diphenyl tetrazolium bromide (Sigma-Aldrich, USA) method. Optical density (OD) values were measured in a microplate spectrophotometer (Molecular Devices, SpectraMax Plus, San

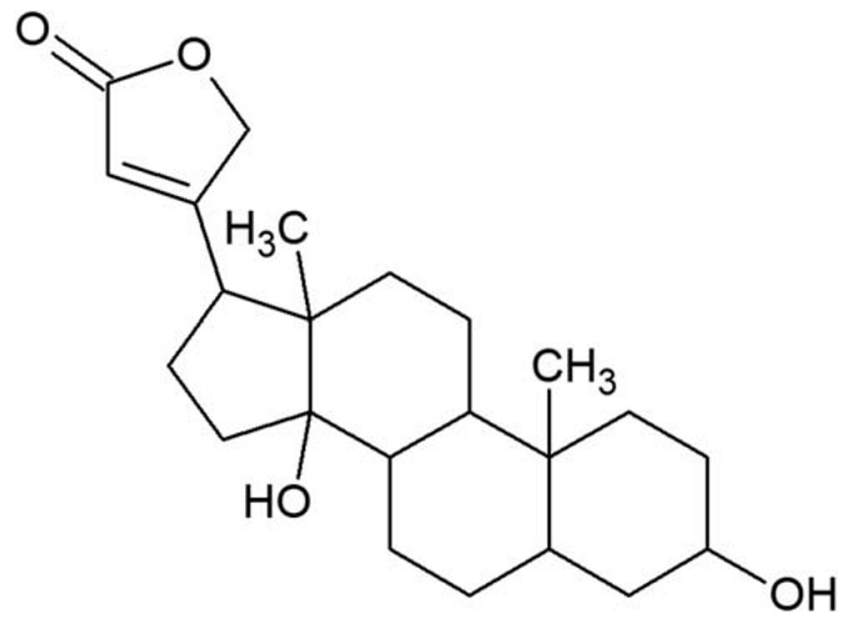

Fig. 1 Chemical structure of digitoxigenin molecule
Jose, CA, USA) at $570 \mathrm{~nm}$. $\mathrm{IC}_{50}$ values were calculated by sigmoidal regression of dose-response curves in Microsoft Excel software (version 10.0) (Tavares et al. 2018).

\section{Cytotoxicity assay}

Cytotoxicity was evaluated ex vivo in murine macrophages and human red blood cells, for which concentrations inhibiting $50 \%$ of macrophages $\left(\mathrm{CC}_{50}\right)$ and red blood cells $\left(\mathrm{RBC}_{50}\right)$ were determined. Briefly, murine cells $\left(5 \times 10^{5}\right)$ or a 5\% human red blood cell suspension were incubated in the presence of DIGI ( 0 to $100.0 \mu \mathrm{g} / \mathrm{mL}$ ) or AmpB (0 to $10.0 \mu \mathrm{g} /$ $\mathrm{mL}$ ) in RPMI 1640 medium for $48 \mathrm{~h}$ (murine macrophages) or $1 \mathrm{~h}$ (red blood cells) at $37^{\circ} \mathrm{C}$ in $5 \% \mathrm{CO}_{2}$. Macrophage viability was assessed by MTT method. The red blood cell suspension was centrifuged at $1000 \times g$ for $10 \mathrm{~min}$ at $4{ }^{\circ} \mathrm{C}$, after which percentage of cell lysis was evaluated spectrophotometrically at $570 \mathrm{~nm}$. The absence of (blank) or 100\% hemolysis was determined by replacing DIGI with an equal volume of phosphate-buffered saline $\mathrm{pH} 7.4$ (PBS) or distilled water, respectively. $\mathrm{CC}_{50}$ and $\mathrm{RBC}_{50}$ values were calculated by sigmoidal regression of dose-response curves in Microsoft Excel software (version 10.0) (Sousa et al. 2019). SI was calculated as the ratio between $\mathrm{CC}_{50}$ and $\mathrm{IC}_{50}$ values.

\section{Treatment of infected macrophages}

To evaluate the efficacy of DIGI for treating infected macrophages, murine cells $\left(5 \times 10^{5}\right)$ were plated on round glass coverslips in 24-well plates in RPMI 1640 medium supplemented with 20\% (v/v) FBS and $20 \mathrm{mM}$ L-glutamine $\mathrm{pH} 7.4$ and incubated for $24 \mathrm{~h}$ at $37{ }^{\circ} \mathrm{C}$ in $5 \% \mathrm{CO}_{2}$. Stationary promastigotes were then added to the wells at a ratio of 10 parasites per macrophage, and cultures were incubated further for $48 \mathrm{~h}$ at $37{ }^{\circ} \mathrm{C}$ in $5 \% \mathrm{CO}_{2}$. Free parasites were removed by extensive washing with RPMI 1640 medium, and infected macrophages were treated with DIGI $(0,2.5,5.0$, and $10.0 \mu \mathrm{g} / \mathrm{mL})$ or AmpB $(0,0.25,0.5$, and $1.0 \mu \mathrm{g} / \mathrm{mL})$ for $48 \mathrm{~h}$ at $24{ }^{\circ} \mathrm{C}$ in $5 \% \mathrm{CO}_{2}$. After fixation with $4 \%$ paraformaldehyde, cells were washed and stained with Giemsa, and the infection percentage, the number of amastigotes per infected macrophage, and the reduction in the infection percentage were determined by counting 200 cells, in triplicate, using an optical microscope (Tavares et al. 2018).

\section{Evaluation of mitochondrial membrane potential and integrity}

Stationary promastigotes $\left(10^{7}\right.$ cells $)$ were cultured in the absence or presence of DIGI $\left(13.8 \mu \mathrm{g} / \mathrm{mL}\right.$, corresponding to $2 \times$ the $\mathrm{IC}_{50}$ value) during $24 \mathrm{~h}$ at $25^{\circ} \mathrm{C}$. Parasites were washed with PBS and incubated with MitoTracker Red CM-H2XROS (500 nM; Invitrogen, USA) or propidium iodide $(1.0 \mu \mathrm{g} / \mathrm{mL}$; SigmaAldrich) for 30 and $15 \mathrm{~min}$, respectively, in the dark and at room 
temperature. After washing twice with PBS, samples were added to a black 96-well plate, and fluorescence intensity was measured using a fluorometer (FLx800, BioTek Instruments, Inc., Winooski, VT, USA), with excitation and emission wavelengths of 540 and $600 \mathrm{~nm}$, respectively. Carbonyl cyanide4-(trifluoromethoxy)phenylhydrazon (FCCP, 5.0 $\mu \mathrm{M}$; SigmaAldrich, USA) and pre-heated parasites at $65^{\circ} \mathrm{C}$ for $10 \mathrm{~min}$ were used as positive controls (Sousa et al. 2019).

\section{Production of reactive oxygen species}

Stationary promastigotes $\left(10^{7}\right.$ cells $)$ were cultured in the absence or presence of DIGI $\left(13.8 \mu \mathrm{g} / \mathrm{mL}\right.$, corresponding to $2 \times$ the $\mathrm{IC}_{50}$ value) for $24 \mathrm{~h}$ at $25^{\circ} \mathrm{C}$. Parasites were washed with PBS and incubated with $20 \mu \mathrm{M}$ cell-permeant $2^{\prime}, 7^{\prime}$ dichlorodihydrofluorescein diacetate $\left(\mathrm{H}_{2} \mathrm{DCFDA}\right.$; SigmaAldrich, USA) for $30 \mathrm{~min}$ in the dark and at room temperature. After washing twice with PBS, samples were added to a black 96-well plate, and fluorescence intensity was measured using a fluorometer (FLx800, BioTek Instruments, Inc., Winooski, VT, USA), with excitation and emission wavelengths of 485 and 528 $\mathrm{nm}$, respectively. $\mathrm{H}_{2} \mathrm{O}_{2}$-treated parasites $(4.0 \mathrm{mM}$; SigmaAldrich, USA) were used as positive control (Sousa et al. 2019).

\section{Infection, treatment, and toxicity assay}

Mice ( $n=12$ per group) were infected subcutaneously with $10^{7}$ L. infantum stationary-phase promastigotes and 60 days post-infection; they were grouped and treated with one of the following therapeutic regimens: $50 \mu \mathrm{L}$ of PBS (saline group), $50 \mu \mathrm{L}$ of empty micelles (10 mg/kg body weight) (B/Mic group), $2 \mathrm{mg}$ miltefosine/ $\mathrm{kg}$ body weight (miltefosine group), $50 \mu \mathrm{L}$ of free DIGI ( $5 \mathrm{mg} / \mathrm{kg}$ body weight) (DIGI group), or $50 \mu \mathrm{L}$ of DIGI-containing micelles $(5 \mathrm{mg} / \mathrm{kg}$ body weight) (DIGI/Mic group). Except for miltefosine which was administered orally, all other regimens were administered subcutaneously, every 2 days for a total period of 10 days. Half of the animals were euthanized 1 and 15 days post-therapy, when biochemical, immunological, and parasitological analyses were performed. To evaluate toxicity in vivo, sera samples from the infected and then treated mice were collected 1 and 15 days post-treatment, with which the levels of aspartate aminotransferase (AST), alanine aminotransferase (ALT), and creatine kinase - muscle brain fraction (CK-MB) markers were measured using commercial kits (Labtest Diagnostica ${ }^{\circledR}$, Belo Horizonte), according to the manufacturer's instructions.

\section{Cytokine and nitrite production}

The spleens were collected from the infected and treated mice 1 and 15 days post-treatment and spleen cells $\left(5 \times 10^{6}\right.$ cells/ $\mathrm{mL}$ ) were incubated in DMEM (medium) supplemented with
$20 \%$ (v/v) FBS and $20 \mathrm{mM}$ L-glutamine at pH 7.4 or stimulated with $L$. infantum soluble Leishmania antigen (SLA, 50 $\mu \mathrm{g} / \mathrm{mL}$ ) for $48 \mathrm{~h}$ at $37{ }^{\circ} \mathrm{C}$ in $5 \% \mathrm{CO}_{2}$. IFN- $\gamma$, IL-4, IL-10, IL$12 \mathrm{p} 70$, and GM-CSF levels were measured in the culture supernatant by capture ELISA technique, using commercial kits (BD PharMingen ${ }^{\circledR}$, San Diego, CA, USA) according to the manufacturer's instructions. Nitrite production was evaluated in these same supernatants by Griess method. The IFN- $\gamma$ source in miltefosine-, DIGI-, and DIGI/Mic-treated mice was evaluated by addition of anti-CD4 (GK 1.5) or antiCD8 (53-6.7) monoclonal antibodies (5 $\mu \mathrm{g}$ each; PharMingen $\AA$, USA) to the stimulated cultures. Appropriate isotype-matched controls (rat IgG2a (R35-95) and rat IgG2b (95-1)) were used. In addition, IFN- $\gamma$, TNF- $\alpha$, and IL-10producing $\mathrm{CD}^{+}$and $\mathrm{CD} 8^{+} \mathrm{T}$ cell frequency were evaluated in the saline-, B/Mic-, miltefosine-, DIGI-, and DIGI/Mictreated mice by flow cytometry using cells collected 15 days post-treatment. Briefly, splenocytes $\left(5 \times 10^{6}\right.$ cells $\left./ \mathrm{mL}\right)$ were cultured in RPMI 1640 (medium) or stimulated with SLA (50 $\mu \mathrm{g} / \mathrm{mL}$ ) for $48 \mathrm{~h}$ at $37^{\circ} \mathrm{C}$ in $5 \% \mathrm{CO}_{2}$. IFN- $\gamma$, TNF- $\alpha$, and IL10-producing $\mathrm{CD}^{+}$and $\mathrm{CD} 8^{+} \mathrm{T}$ cell frequency were determined by their relative flow cytometry size (forward laser scatter-FSC) and granularity (side laser scatter-SSC). After selection of the R1 region of containing FSCLow and SSCLow phenotype cells, IFN- $\gamma^{+}$, TNF- $\alpha$, and IL- $10^{+}$, T cell frequency was calculated based on the analysis of density plot distribution of CD4/FL1 or CD8/FL1 versus IFN- $\gamma / \mathrm{FL}^{+}$, TNF- $\alpha / \mathrm{FL}^{+}$, and IL-10/FL2 ${ }^{+}$cells. Results were expressed as indexes, which were calculated as the ratio between $\mathrm{CD}^{+}$ and $\mathrm{CD} 8^{+} \mathrm{T}$ cell percentages in the stimulated versus unstimulated (control) cultures (Mendonça et al. 2018).

\section{Humoral response}

The levels of antiparasite IgG1 and IgG2a isotype antibodies in sera samples collected from infected and treated mice were evaluated by ELISA assay, 1 and 15 days post-treatment. L. infantum SLA was used as antigen $(1.0 \mu \mathrm{g} / \mathrm{well})$, and sera samples were diluted 1:100 in PBS-T (PBS plus $0.05 \%(\mathrm{v} / \mathrm{v})$ Tween 20). Antimouse IgG1 and IgG2a horseradishperoxidase conjugated antibodies (Sigma-Aldrich, USA) were used at a 1:10,000 dilution in PBS-T. Reactions were developed using $\mathrm{H}_{2} \mathrm{O}_{2}$, ortho-phenylenediamine, and citratephosphate buffer at $\mathrm{pH} 5.0$ for $30 \mathrm{~min}$ and in the dark and stopped by addition of $2 \mathrm{~N} \mathrm{H}_{2} \mathrm{SO}_{4}$. OD values were measured in an ELISA microplate spectrophotometer (Molecular Devices, SpectraMax Plus, Canada) at $492 \mathrm{~nm}$.

\section{Parasite load}

Parasite load in the spleens, livers, BMs, and dLNs collected from the infected and treated mice 1 and 15 days posttreatment was evaluated by limiting dilution technique 
Table 1 In vitro biological assays. L. infantum stationary promastigotes $\left(10^{6}\right.$ cells) were incubated with DIGI (0 to $50 \mu \mathrm{g} / \mathrm{mL}$ ) or AmpB (0 to 1.0 $\mu \mathrm{g} / \mathrm{mL}$ ) for $48 \mathrm{~h}$ at $24{ }^{\circ} \mathrm{C}$. Cell viability was analyzed by MTT method, and $50 \%$ Leishmania inhibitory concentration $\left(\mathrm{IC}_{50}\right)$ was calculated by sigmoidal regression of the corresponding dose-response curve. Murine macrophages were incubated with DIGI ( 0 to $100 \mu \mathrm{g} / \mathrm{mL})$ or AmpB (0 to $10.0 \mu \mathrm{g} / \mathrm{mL}$ ), and $50 \%$ macrophage inhibitory concentration $\left(\mathrm{CC}_{50}\right)$ was determined by sigmoidal regression of dose-response curves. The selectivity index (SI) was calculated as the ratio between $\mathrm{CC}_{50}$ and $\mathrm{IC}_{50}$ values; $50 \%$ inhibition of human red blood cells $\left(\mathrm{RBC}_{50}\right)$ viability was calculated by incubating a $5 \%$ red blood cell suspension with DIGI $(0$ to $100.0 \mu \mathrm{g} / \mathrm{mL}$ ) or $\mathrm{AmpB}$ (0 to $10.0 \mu \mathrm{g} / \mathrm{mL}$ ) for $1 \mathrm{~h}$ at $37^{\circ} \mathrm{C}$ in $5 \% \mathrm{CO}_{2}$. Percentage of cell lysis was evaluated spectrophotometrically, and the absences of (blank) and 100\% hemolysis were determined by replacing DIGI for an equal volume of PBS and distilled water, respectively. Results were expressed as mean \pm standard deviation

\begin{tabular}{lllll}
\hline Compound & $\mathrm{IC}_{50}(\mu \mathrm{g} / \mathrm{mL})$ & $\mathrm{CC}_{50}(\mu \mathrm{g} / \mathrm{mL})$ & $\mathrm{SI}$ & $\mathrm{RBC}_{50}(\mu \mathrm{g} / \mathrm{mL})$ \\
\hline Digitoxigenin & $6.9 \pm 1.5$ & $295.3 \pm 14.5$ & 42.8 & $384.6 \pm 20.4$ \\
Amphotericin B & $0.13 \pm 0.02$ & $0.79 \pm 0.12$ & 6.1 & $11.7 \pm 2.3$ \\
\hline
\end{tabular}

(Tavares et al. 2018). Briefly, organs were macerated in a glass tissue grinder using sterile PBS, and tissue debris was removed by centrifugation at $150 \times g$. Cells were concentrated by centrifugation at $2000 \times g$, resuspended in $1 \mathrm{~mL}$ of complete Schneider's medium, and serially diluted $10^{-1}$ to $10^{-12}$ in the same medium. Each sample was plated in triplicate and cultured at $24^{\circ} \mathrm{C}$ for 7 days. Results were expressed as the negative $\log$ of the titer (the dilution corresponding to the last positive well) adjusted per milligram of organ.

\section{Splenic parasitism}

The splenic parasite load was evaluated also by qPCR technique, as described previously (Duarte et al. 2016; Antonia et al. 2018). Briefly, spleen DNA was extracted and resuspended, and the parasite load was estimated by qPCR using the primers forward (CCTATTTTACACCAACCCCCAGT) and reverse (GGGTAGGGGCGTTCTGCGAAA). Mouse $\beta$-actin gene (forward: CAGAGCAAGAGAGGTATCC and reverse: TCATTGTAGAAGGTGTGGTGC) was used as an endogenous control. Reactions were processed in an ABI Prism 7500 Sequence Detection System (96-well plate; Applied Biosystems) using $2 \times$ SYBR $^{\mathrm{TM}}$ Select Master Mix $(5 \mu \mathrm{L}$; Applied Biosystems, USA) supplemented with each primer at a final concentration of $2 \mathrm{mM}(1 \mu \mathrm{L})$ and $4 \mu \mathrm{L}$ of DNA $(25 \mathrm{ng} / \mu \mathrm{L})$. Samples were incubated at $95^{\circ} \mathrm{C}$ for $10 \mathrm{~min}$ and submitted to 40 cycles of $15 \mathrm{~s}$ at $95^{\circ} \mathrm{C}$ followed by $1 \mathrm{~min}$ at $60^{\circ} \mathrm{C}$. After each cycle, fluorescence data were collected. A standard curve was run in parallel, which was performed in duplicate and expressed as the number of $L$. infantum organisms per total DNA.

\section{Statistical analysis}

Statistical analysis was performed using GraphPad Prism ${ }^{\mathrm{TM}}$ (version 6.0 for Windows). Results were analyzed using oneway analysis of variance (ANOVA) followed by Bonferroni's post-test for comparison between the groups. Results were expressed as mean \pm standard deviation. Two independent experiments, presenting similar results, were performed. Differences were considered significant when $P<0.05$.

\section{Results}

\section{Analysis of antileishmanial activity, cytotoxicity, and treatment of infected macrophages}

Antileishmanial activity $\left(\mathrm{IC}_{50}\right)$ and cytotoxicity $\left(\mathrm{CC}_{50}\right)$ were evaluated against $L$. infantum stationary promastigotes and
Table 2 Treatment of infected macrophages. Murine macrophages $(5 \times$ $10^{5}$ cells) were incubated in RPMI 1640 medium supplemented with $20 \%$ (v/v) FBS and $20 \mathrm{mM} \mathrm{L}$-glutamine at $\mathrm{pH} 7.4$, for $24 \mathrm{~h}$ at $37^{\circ} \mathrm{C}$ in $5 \% \mathrm{CO}_{2}$. L. infantum stationary promastigotes were used to infect macrophages (at a ratio of 10 parasites per macrophage) for $48 \mathrm{~h}$ at $37^{\circ} \mathrm{C}$ in $5 \% \mathrm{CO}_{2}$. Free parasites were removed by extensive washing with medium and infected macrophages were treated with DIGI $(0,2.5,5.0$, and $10.0 \mu \mathrm{g} / \mathrm{mL})$ or $\operatorname{AmpB}(0,0.25,0.5$, and $1.0 \mu \mathrm{g} / \mathrm{mL})$ for $48 \mathrm{~h}$ at $37^{\circ} \mathrm{C}$ in $5 \% \mathrm{CO}_{2}$. The percentage of infected macrophages, the infectiveness reduction, and the number of amastigotes per infected macrophage were determined by counting 200 cells in triplicate. Results were expressed as mean \pm standard deviation

\begin{tabular}{|c|c|c|c|c|}
\hline Compound & Concentration $(\mu \mathrm{g} / \mathrm{mL})$ & $\begin{array}{l}\text { Percentage of infected } \\
\text { macrophages after treatment }\end{array}$ & Infectiveness reduction (\%) & $\begin{array}{l}\text { Number of amastigotes } \\
\text { per macrophage }\end{array}$ \\
\hline \multirow[t]{4}{*}{ Digitoxigenin } & 10.0 & $21.1 \pm 2.5$ & 69.3 & $0.5 \pm 0.1$ \\
\hline & 5.0 & $30.5 \pm 4.0$ & 55.6 & $1.0 \pm 0.4$ \\
\hline & 2.5 & $44.4 \pm 3.8$ & 35.4 & $2.3 \pm 0.6$ \\
\hline & 0 & $68.7 \pm 4.0$ & $(-)$ & $3.9 \pm 0.5$ \\
\hline \multirow[t]{4}{*}{ Amphotericin B } & 1.0 & $23.4 \pm 3.3$ & 65.9 & $1.0 \pm 0.2$ \\
\hline & 0.50 & $32.1 \pm 3.8$ & 53.3 & $1.4 \pm 0.3$ \\
\hline & 0.25 & $44.5 \pm 5.2$ & 35.2 & $2.5 \pm 0.9$ \\
\hline & 0 & $68.7 \pm 4.0$ & $(-)$ & $3.9 \pm 0.5$ \\
\hline
\end{tabular}


Table 3 Infection percentage using pre-treated parasites

\begin{tabular}{lllll}
\hline Compound & $\begin{array}{l}\text { Concentration } \\
(\mu \mathrm{g} / \mathrm{mL})\end{array}$ & $\begin{array}{l}\text { Infection percentage using } \\
\text { pre-treated parasites }\end{array}$ & $\begin{array}{l}\text { Infectiveness } \\
\text { reduction }(\%)\end{array}$ & $\begin{array}{l}\text { Number of amastigotes } \\
\text { per macrophage }\end{array}$ \\
\hline Digitoxigenin & 10.0 & $9.5 \pm 1.4$ & 86.5 & $0.2 \pm 0.1$ \\
& 5.0 & $16.7 \pm 1.6$ & 76.2 & $0.8 \pm 0.3$ \\
& 2.5 & $31.2 \pm 3.5$ & 55.6 & $1.8 \pm 0.4$ \\
Amphotericin B & 0 & $70.3 \pm 4.3$ & $(-)$ & $3.9 \pm 0.4$ \\
& 1.0 & $25.4 \pm 3.0$ & 63.9 & $1.2 \pm 0.3$ \\
& 0.50 & $32.4 \pm 5.1$ & 53.9 & $1.8 \pm 0.5$ \\
& 0.25 & $49.3 \pm 3.2$ & 29.9 & $2.6 \pm 0.3$ \\
& 0 & $70.3 \pm 4.3$ & $(-)$ & $3.9 \pm 0.4$ \\
\hline
\end{tabular}

murine macrophages, respectively. Results showed $\mathrm{IC}_{50}$ and $\mathrm{CC}_{50}$ values of $6.9 \pm 1.5$ and $295.3 \pm 14.5 \mu \mathrm{g} / \mathrm{mL}$ for DIGI, respectively, with a corresponding SI value of 42.8, and of $0.13 \pm 0.02$ and $0.79 \pm 0.12 \mu \mathrm{g} / \mathrm{mL}$ for AmpB, respectively, with a SI value of 6.1 (Table 1). The hemolytic activity in human red blood cells showed $\mathrm{RBC}_{50}$ values of $384.6 \pm$ 20.4 and $11.7 \pm 2.3 \mu \mathrm{g} / \mathrm{mL}$ for DIGI and AmpB, respectively. Infection percentages of treated macrophages were of $21.1 \% \pm$ $2.5 \%$ for DIGI $(10.0 \mu \mathrm{g} / \mathrm{mL})$ and of $23.4 \% \pm 3.3 \%$ for AmpB $(1.0 \mu \mathrm{g} / \mathrm{mL})$, with $0.5 \pm 0.1$ and $1.0 \pm 0.2$ amastigotes per infected macrophage, respectively (Table 2 ). If left untreated,

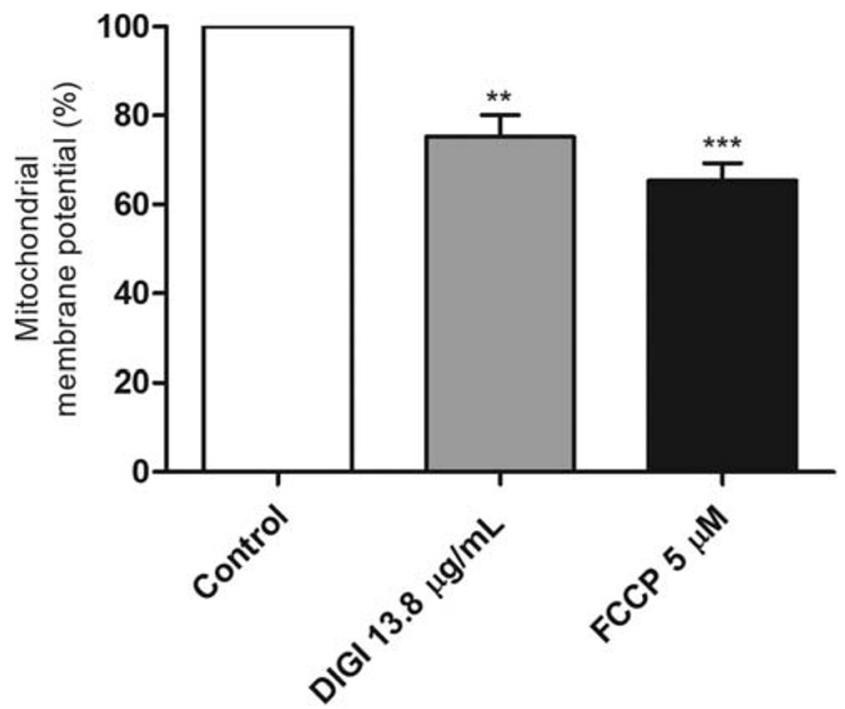

Fig. 2 Evaluation of mitochondrial membrane potential. L. infantum stationary promastigotes $\left(10^{7}\right.$ cells $)$ were cultured in the absence (control) or presence of DIGI $(33.80 \mu \mathrm{g} / \mathrm{mL}$, corresponding to two times the $\mathrm{IC}_{50}$ value) for $24 \mathrm{~h}$ at $25^{\circ} \mathrm{C}$. Cells were incubated for $30 \mathrm{~min}$ in the dark with $500 \mathrm{nM}$ MitoTracker Red CM-H2XROS. After washing twice with PBS, treated promastigotes were transferred to a black 96-well plate, and fluorescence intensity was measured using a fluorometer, with excitation and emission wavelengths of 540 and $600 \mathrm{~nm}$, respectively. Promastigotes pre-heated with carbonyl cyanide-4(trifluoromethoxy)phenylhydrazon (FCCP, $5.0 \mu \mathrm{M}$ ) were used as positive control. Bars indicate the mean plus standard deviation of the groups. Double asterisks and triple asterisks indicate statistically significant differences in relation to the non-treated control $(P<0.01$ and $P<0.001$, respectively) the infection percentage and number of amastigote per infected macrophage were of $68.7 \% \pm 4.0 \%$ and $3.9 \pm 0.5$, respectively. The inhibition of infection using pre-treated parasites showed also that DIGI caused significant reduction in the parasite infection degree after incubation with it (Table 3).

\section{Evaluation of the mechanism of action in L. infantum promastigotes}

A proof of concept for the mechanism of action of DIGI was evaluated in L. infantum stationary promastigotes. Results showed that the molecule caused an alteration in the $\Delta \Psi \mathrm{m}$

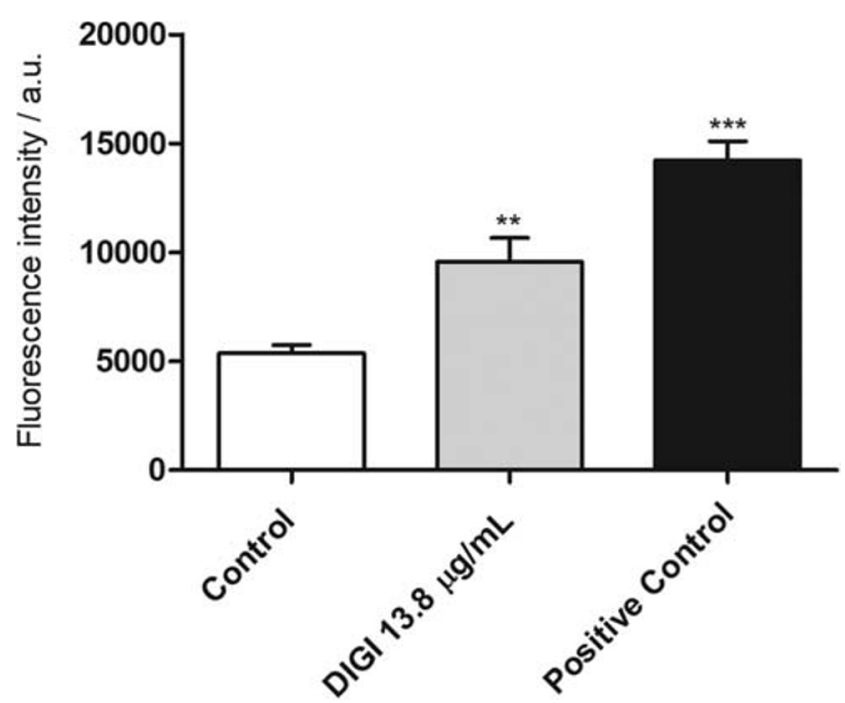

Fig. 3 Evaluation of mitochondrial membrane integrity. Stationary promastigotes $\left(10^{7}\right.$ cells) were cultured in the absence (control) or presence of DIGI $\left(13.8 \mu \mathrm{g} / \mathrm{mL}\right.$, corresponding to two times the $\mathrm{IC}_{50}$ value) for $24 \mathrm{~h}$ at $25^{\circ} \mathrm{C}$. Parasites were washed in PBS and incubated with propidium iodide $(1.0 \mu \mathrm{g} / \mathrm{mL})$ for $15 \mathrm{~min}$ in the dark and at room temperature. After washing twice with PBS, samples were added to a black 96-well plate, and fluorescence intensity was measured using a fluorometer (FLx800, BioTek Instruments, Inc., Winooski, VT, USA), with excitation and emission wavelengths of 540 and $600 \mathrm{~nm}$, respectively. Pre-heated parasites for $10 \mathrm{~min}$ at $65{ }^{\circ} \mathrm{C}$ were used as positive control. Bars indicate the mean plus standard deviation of the groups. Double asterisks and triple asterisks indicate statistically significant differences in relation to the non-treated control $(P<0.01$ and $P<0.001$, respectively) 


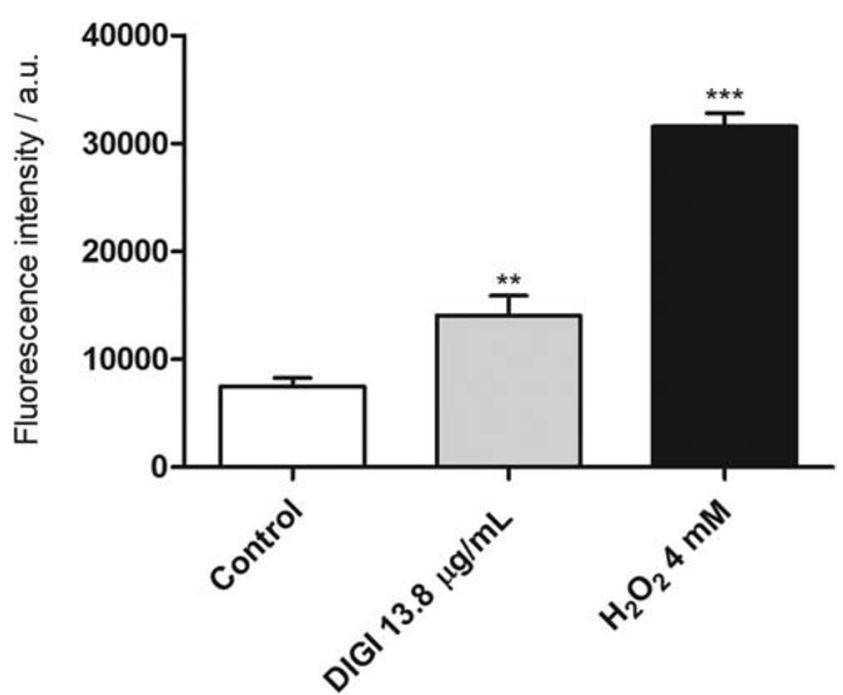

Fig. 4 Production of reactive oxygen species. L. infantum promastigotes $\left(10^{7}\right.$ cells) were cultured in the absence (control) or presence of DIGI $\left(13.8 \mu \mathrm{g} / \mathrm{mL}\right.$, corresponding to two times the $\mathrm{IC}_{50}$ value) for $24 \mathrm{~h}$ at 25 ${ }^{\circ} \mathrm{C}$. Cells were incubated for $30 \mathrm{~min}$ in the dark with $20 \mu \mathrm{M}$ cell-permeant $2^{\prime}, 7^{\prime}$-dichlorodihydrofluorescein diacetate $\left(\mathrm{H}_{2} \mathrm{DCFDA}\right)$. Fluorescence intensity was measured using a fluorometer, with excitation and emission wavelengths of 485 and $528 \mathrm{~nm}$, respectively. $\mathrm{H}_{2} \mathrm{O}_{2}$-treated parasites $(4.0 \mathrm{mM})$ were used as positive control. Bars indicate the mean plus standard deviation of the groups. Double asterisks and triple asterisks indicate statistically significant differences in relation to the nontreated control $(P<0.01$ and $P<0.001$, respectively $)$

in the order of $24.8 \%$, when compared with the untreated controls, while FCCP-treated promastigotes, used as positive control, showed a value of $30.9 \%$ (Fig. 2). Treatment with DIGI generated also structural alterations on the integrity of Leishmania membrane in the order of $78.6 \%$, in comparison with an alteration of $165.3 \%$ caused by heat treatment of the parasites (control) (Fig. 3). In addition, treatment with DIGI resulted in parasite oxidative stress with an increase in ROS levels of $87.5 \%$, compared with an increase of $321.0 \%$ after treatment with $\mathrm{H}_{2} \mathrm{O}_{2}$ used as a control (Fig. 4).

\section{Analysis of treatment toxicity}

Organic toxicity of DIGI was evaluated by dosage of hepatic and cardiac markers in sera samples collected from the infected and treated mice, 1 and 15 days post-treatment. Results showed that miltefosine-, DIGI-, and DIGI/Mic-treated mice presented lower levels of alanine aminotransferase (ALT) (Fig. 5a), aspartate transaminase (AST) (Fig. 5b), and creatine kinasemuscle brain fraction (CK-MB) (Fig. 5c) enzymes, when compared with the controls. Notably, DIGI/Mictreated mice presented the lowest levels of both hepatic and cardiac markers in comparison with the other treated groups.

\section{Evaluation of the immune response generated after treatment}

The cellular response to treatment after infection was evaluated 1 and 15 days post-treatment on in vitro cultures of murine spleen cells, with were stimulated with SLA $L$. infantum. One day after therapy, miltefosine-, DIGI-, and DIGI/Mic-treated mice produced significantly higher levels of IFN- $\gamma$, IL-12, and GM-CSF, associated with low IL-4 and IL-10 production. On the other hand, spleen cells of the control groups (salineand $\mathrm{B} /$ Mic-receiving mice) produced significantly higher levels of antileishmanial IL-4 and IL-10 (Fig. 6a). Analysis of the source of IFN- $\gamma$ production in the treated animals using anti-CD4 or anti-CD8 monoclonal antibodies showed that the production of this cytokine declined significantly when both monoclonal antibodies were added to the cultures (Fig. 6b). Evaluation of the humoral response indicated also that miltefosine-, DIGI-, and DIGI/Mic-treated mice produced significantly higher levels of antiparasite IgG2a antibody in comparison with IgG1 (Fig. 6c). Furthermore, evaluation of nitrite secretion in the cell supernatant showed significantly higher levels of this molecule in miltefosine-, DIGI-, or DIGI/Mictreated mice, when compared with the controls (Fig. 6d). All data mentioned above corresponding to 1 day after therapy were consistent with findings 15 days post-treatment, since miltefosine-, DIGI-, and DIGI/Mic-treated mice continued to produce significantly higher levels of IFN- $\gamma$, IL-12, and GMCSF, as well as low IL-4 and IL-10 levels (Fig. 7a). As observed 1 day post-treatment, both $T$ cell subtypes continued to produce IFN- $\gamma$ after 15 days of therapy (Fig. 7b), with a maintained Th1-type humoral response corresponding to significantly higher levels of antiparasite IgG2a isotype antibodies in comparison with IgG1 levels (Fig. 7c). Nitrite secretion was likewise increased in the miltefosine-, DIGI-, and DIGI/Mictreated groups (Fig. 7d). Moreover, a flow cytometry analysis revealed that miltefosine-, DIGI-, and DIGI/Mic-treated mice presented higher IFN- $\gamma$ and TNF- $\alpha$-producing $\mathrm{CD}^{+}$and $\mathrm{CD} 8^{+} \mathrm{T}$ cell frequencies when compared with the control groups, which instead showed a higher IL-10-producing T cell frequency (Fig. 8).

\section{Analysis of parasite load after treatment}

The parasite load in the spleen, liver, BM, and dLNs of the infected and treated mice was evaluated 1 and 15 days posttherapy. Results showed that mice treated with miltefosine, DIGI, and DIGI/Mic presented significant reductions in the parasitism in these organs, when compared with the controls (Fig. 9). One day post-therapy, miltefosine-, DIGI-, and DIGI/Mic-treated mice showed parasite load reductions in the order of 2.3, 2.7, and 3.7-log in their livers (Fig. 9a), of 3.0, 3.7, and 4.7-log in their spleens (Fig. 9b), of 3.6, 5.0, and 6.0-log in their dLNs (Fig. 9c) and of 1.6, 2.0, and 2.6-log in 
Fig. 5 Evaluation of organic toxicity. Alanine

aminotransferase (ALT) (a), aspartate aminotransferase (AST) (b), and creatine kinase-muscle brain fraction (CK-MB) (c) enzymes were measured in sera samples of infected and treated mice, collected 1 and 15 days post-treatment. Samples collected from non-infected and nontreated (naive) mice were used as control. Bars represent the mean \pm standard deviation of the groups. Single asterisk indicates a statistically significant difference in relation to the saline and $\mathrm{B} / \mathrm{Mic}$ groups $(P<0.05)$. Double asterisks indicate a statistically significant difference in relation to the miltefosine group $(P<$ $0.05)$. Triple asterisks indicate a statistically significant difference in relation to the DIGI group $(P<$ 0.05 )
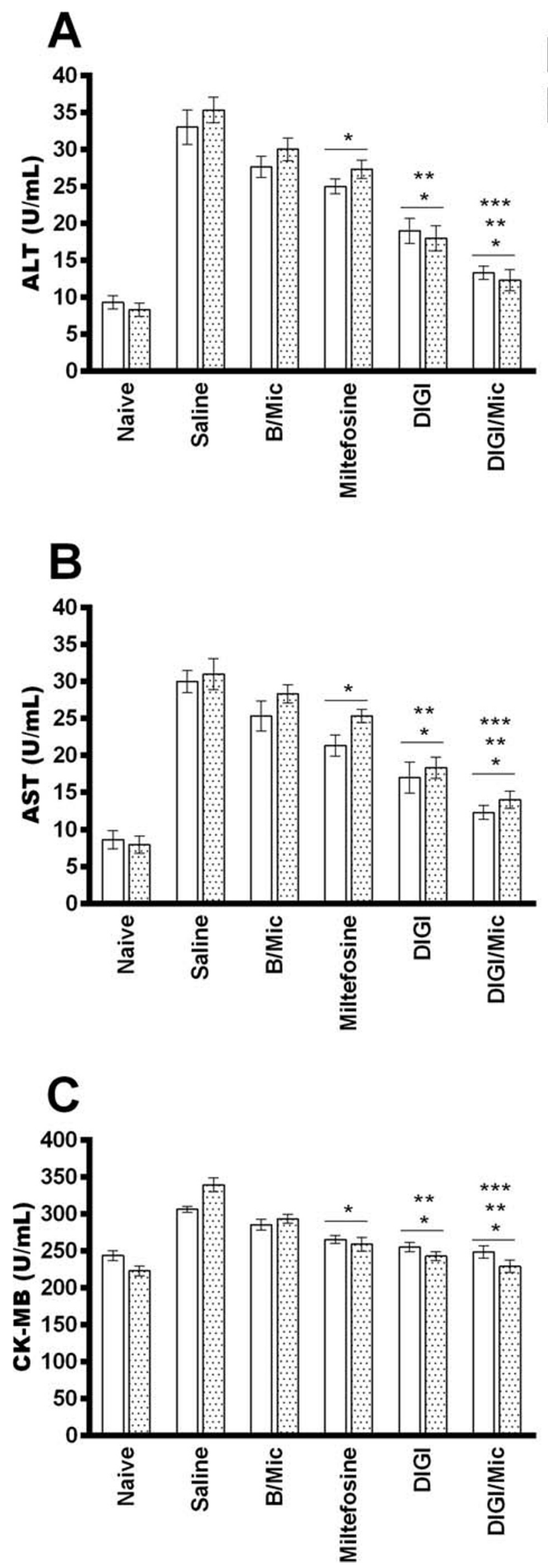


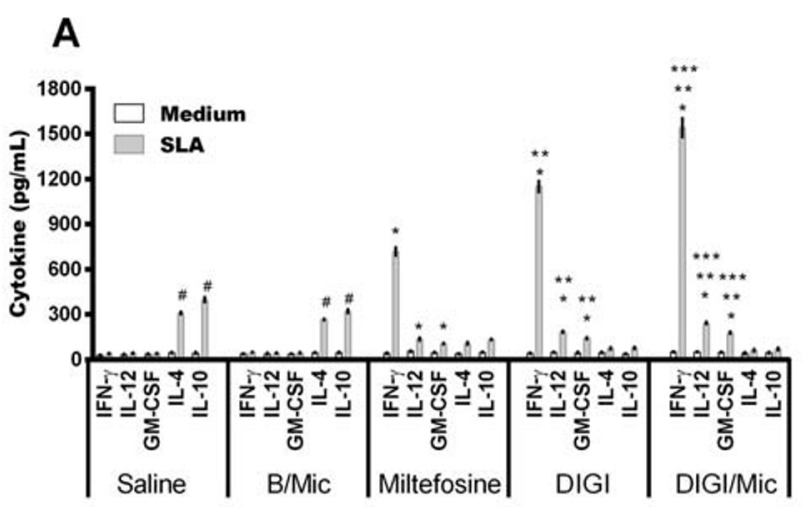

B

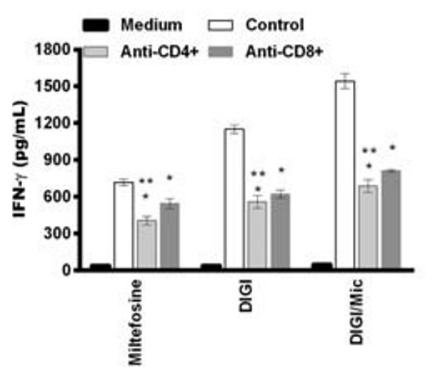

Fig. 6 Immune response developed one day after treatment. The spleens of the $L$. infantum-infected and then treated mice ( $n=6$ per group) were collected 1 day after treatment. Spleen cells were cultured in vitro in DMEM (medium) in the absence of stimulus or stimulated with SLA $(50.0 \mu \mathrm{g} / \mathrm{mL})$ for $48 \mathrm{~h}$ at $37{ }^{\circ} \mathrm{C}$ in $5 \% \mathrm{CO}_{2}$. IFN- $\gamma$, IL-4, IL-10, IL$12 \mathrm{p} 70$, and GM-CSF levels were measured in the cell supernatant by capture ELISA (a). The cultures were incubated also in the absence or presence of anti-CD4 or anti-CD8 monoclonal antibodies $(5 \mu \mathrm{g} / \mathrm{mL}$ each) for $48 \mathrm{~h}$ at $37^{\circ} \mathrm{C}$ in $5 \% \mathrm{CO}_{2}$. IFN- $\gamma$ production was then evaluated in the cell supernatant (b). Murine sera samples were collected. Antiparasite IgG1 and IgG2a antibody levels were measured by indirect ELISA, and

their BMs (Fig. 9a), respectively, when compared with the saline group. Fifteen days post-treatment, reductions in these groups were of 2.6, 3.6, and 4.6-log in their livers; of 3.3, 4.0, and 5.3-log in their spleens; of 3.6, 5.0, and 6.0-log in their dLNs; and of 1.7, 2.3, and 3.0-log in their BMs, respectively, when compared with the saline group. Notably, treatment with DIGI/Mic induced the most significant reductions in the organic parasitism, when compared with the other treated groups. A qPCR technique showed also that the splenic parasitism was significantly reduced after treatment with miltefosine, DIGI, or DIGI/Mic, and mice receiving DIGI/Mic presented the lowest parasite load, when compared with the other groups (Fig. 10).

\section{Discussion}

The aim of the present study was to evaluate potential antileishmanial activity of digitoxigenin, a cardenolide derivate, against stationary promastigotes and intracellular amastigotes and on a murine model which was previously
D

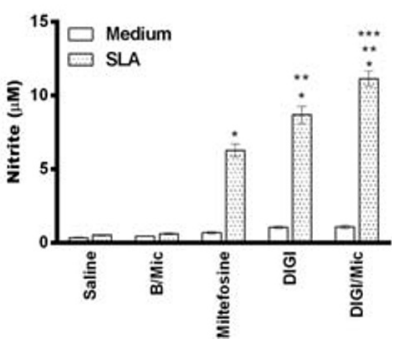

the corresponding $\operatorname{IgG} 2 \mathrm{a} / \mathrm{IgG} 1$ ratios were calculated (c). The cell supernatant used to quantify cytokines (a) was also employed to evaluate nitrite production, and results are shown in panel (d). Bars indicate the mean \pm standard deviation of the groups. $\left(^{*}\right)$ indicate a statistically significant difference in relation to the saline and $\mathrm{B} / \mathrm{Mic}$ groups $(P<0.05)$. Single asterisk indicates a statistically significant difference in relation to the miltefosine group $(P<0.05)$. Triple asterisks indicate a statistically significant difference in relation to the DIGI group $(P<0.05)$. Number sign indicates a statistically significant difference in relation to the miltefosine, DIGI, and DIGI/Mic groups $(P<$ $0.05)$

infected with $L$. infantum promastigotes. Initially, in vitro results showed that DIGI reduced by $69.3 \%$ the intracellular parasite burden in treated macrophages and by $86.5 \%$ the infection of these cells using pre-treated parasites. In comparison, AmpB showed values of $65.9 \%$ and $63.9 \%$, respectively. In vivo, treatment with DIGI or DIGI/Mic significantly reduced the parasite load in the spleen, liver, BM, and dLNs of infected mice, 1 and 15 days after treatment, both outperforming miltefosine. These observations suggest a therapeutic action of DIGI against $L$. infantum infection.

Cardenolides have been used for the treatment of congestive heart failure and atrial arrhythmias (Scalese and Salvatore 2017; Whayne 2018). They act as inhibitors of the $\mathrm{Na}^{+} / \mathrm{K}^{+}$ATPase by suppressing the sodium pump (Patel et al. 2019). In our study, preliminary data suggest that DIGI targets the L. infantum mitochondria, causing alterations in both the parasite mitochondrial membrane potential and integrity, as well as an increase in ROS production. Loss of mitochondrial membrane potential gives rise to a release of protons from the mitochondria into the cell cytosol, which has been reported to contribute to the cytosol acidification and subsequent 


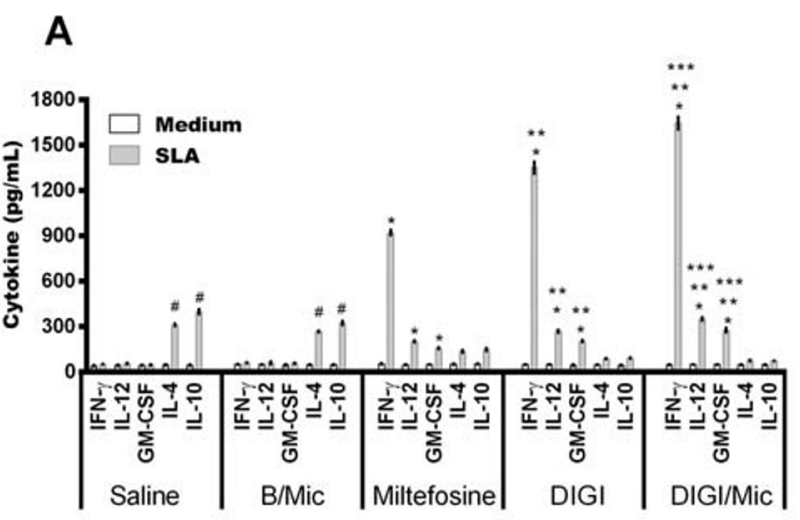

B

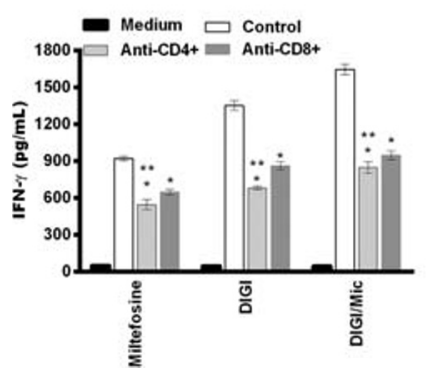

Fig. 7 Immunological profile generated 15 days after treatment. Spleens of the L. infantum-infected and then treated mice ( $n=6$ per group) were collected 15 days after treatment. Spleen cells were cultured in vitro in DMEM (medium) and left untreated or stimulated with SLA $(50.0 \mu \mathrm{g} /$ $\mathrm{mL}$ ) for $48 \mathrm{~h}$ at $37^{\circ} \mathrm{C}$ in $5 \% \mathrm{CO}_{2}$. IFN- $\gamma$, IL-4, IL-10, IL-12p70, and GMCSF levels were measured in the cell supernatant by capture ELISA (a). The cultures were incubated also in the absence or presence of anti-CD4 or anti-CD8 monoclonal antibodies $\left(5 \mu \mathrm{g} / \mathrm{mL}\right.$ each) for $48 \mathrm{~h}$ at $37^{\circ} \mathrm{C}$ in $5 \% \mathrm{CO}_{2}$. IFN- $\gamma$ production was then evaluated in the cell supernatants (b). Murine sera samples were also collected, and anti-parasite IgG1 and IgG2a antibody levels were measured by indirect ELISA. The

parasite death (Su et al. 2019). Thus, experimental data on this study suggest a similar mechanism of action for DIGI in L. infantum. There are several studies reporting the effect of cardenolides in heart diseases (Campbell and Mc Donald 2003; Biteker et al. 2017; Gurel et al. 2017), but evaluation of these compounds to treat VL is lacking. Although cardenolides have been reported as toxic compounds (Hauptman et al. 2016; Arbabian et al. 2018), the low doses of either DIGI on its free form or incorporated into a micellar composition (DIGI/Mic) tested in our study did not induce any significant toxicity when used to treat the infected hosts. Conversely, infected animals receiving miltefosine did present with toxicity.

Antileishmanial drug inductors of immunological response are a key for effective parasite control, since they have a direct action on the Leishmania organisms at the same time they stimulate the development of a specific cellular and humoral response, thus allowing infection control (Kedzierski and Evans 2014; Dayakar et al. 2019). VL control usually depends on the magnitude of the Th1-type cellular response, which leads to the production of cytokines, such as IFN- $\gamma$, and
D

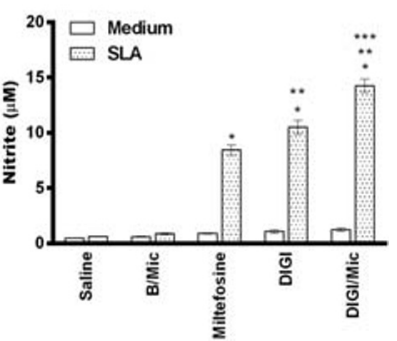

corresponding $\mathrm{IgG} 2 \mathrm{a} / \mathrm{IgG} 1$ ratios were calculated and are displayed in panel (c). The same cell supernatants used to quantify cytokines (a) were also employed to evaluate nitrite production (d). Bars indicate the mean \pm standard deviation of the groups. Single asterisk indicates a statistically significant difference in relation to the saline and $\mathrm{B} / \mathrm{Mic}$ groups $(P<0.05)$. Double asterisks indicate a statistically significant difference in relation to the miltefosine group $(P<0.05)$. Triple asterisks indicate a statistically significant difference in relation to the DIGI group $(P<0.05)$. Number sign indicates a statistically significant difference in relation to the miltefosine, DIGI, and DIGI/Mic groups $(P<$ $0.05)$

subsequent activation of infected macrophages (Kaye et al. 2004). In this context, our results showed that treatment with DIGI or DIGI/Mic induced a significant increase in the levels of Th1-type cytokines, such as IFN- $\gamma$, IL-12, TNF- $\alpha$, and GM-CSF, 1 and 15 days post-treatment. On the other hand, cytokines like IL-4 and IL-10 are associated with progression of VL (Singh et al. 2012; Adem et al. 2016). In our study, treatment with DIGI or DIGI/Mic significantly reduced the levels of IL-4 and IL-10, both 1 and 15 days after therapy, suggesting induction of a DIGI-specific Th1-type immune response profile following treatment.

Antileishmanial candidates have been incorporated into delivery systems to improve their therapeutic efficacy and reduce the toxicity of the corresponding pure compounds (Bruni et al. 2017; Wagner et al. 2019). In previous studies, we showed that micellar compositions using Poloxamer 407 (Pluronic ${ }^{\circledR}$ F127-based polymeric micelles proved effective in mammalian models against Leishmania infection (Duarte et al. 2016; Oliveira-de-Siqueira et al. 2017; Mendonça et al. 2019). In a similar fashion, we also developed a clioquinol (ICHQ)-containing Pluronic ${ }^{\circledR}$ F127 polymeric micelle system 


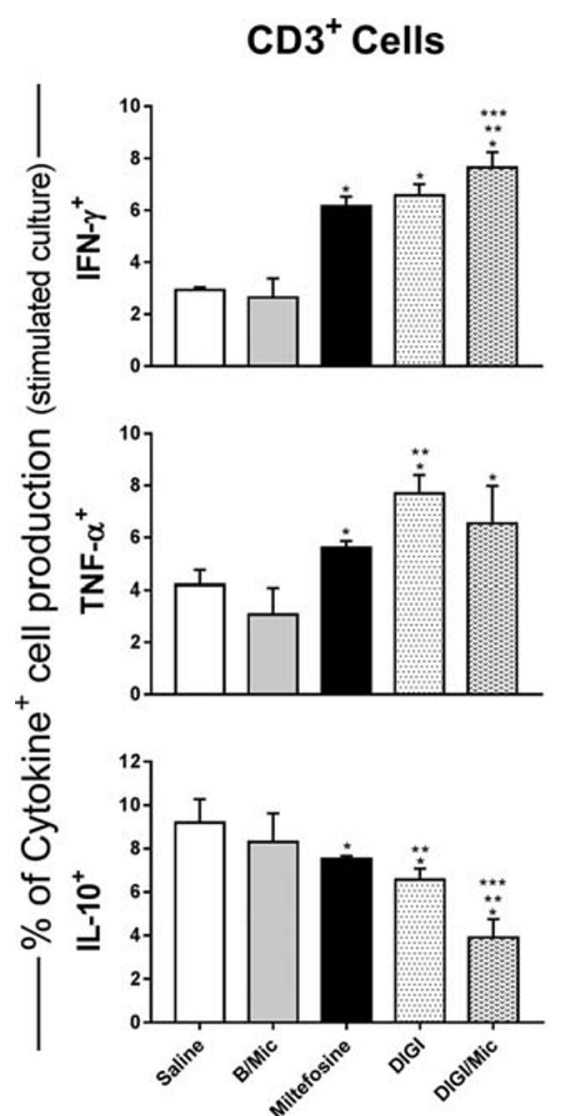

Fig. 8 Evaluation of intracytoplasmic cytokine-producing $\mathrm{T}$ cell frequency. $L$. infantum-infected mice were treated and euthanized 15 days post-therapy, when their spleen cells were collected and left untreated (medium) or stimulated with $L$. infantum SLA. IFN- $\gamma$, TNF$\alpha$, and IL-10-producing T cell frequencies were evaluated in the $\mathrm{CD}^{+}$ and $\mathrm{CD}^{+} \mathrm{T}$ cell subpopulations. Results were expressed as indexes, which were calculated as the ratio between $\mathrm{CD} 4^{+}$and $\mathrm{CD} 8^{+} \mathrm{T}$ cell

(ICHQ/Mic) and tested it against $L$. infantum infection in BALB/c mice (Tavares et al. 2020). In agreement with the data presented in this report, findings on our previous study demonstrated that treatment with miltefosine, ICHQ, or ICHQ/Mic all induced a polarized Th1-type immune response in mice, with significant reductions in the parasite load in distinct organs. Importantly, data proved ICHQ/Mic to be the most effective in inducing immunological and parasitological protection in mice. In a similar fashion, Singh et al. (2017) developed an AmpB-containing micellar formulation based on Pluronic F127 micelles coated with chitosan. The authors showed higher antileishmanial activity in vitro of this composition in comparison with free AmpB, as well as lower cytotoxicity and hemolytic activity in mammalian cells. In addition, this micellar composition reduced the parasite load in $L$. donovani-infected Syrian hamsters, apart from stimulating the development of a Th1-type immune response in the treated animals. In this context, our current report is in complete agreement with our previous studies and with others described in the literature, with DIGI showing
$\mathrm{CD}^{+} \mathrm{T}$-Cells

CD8 $^{+}$T-Cells
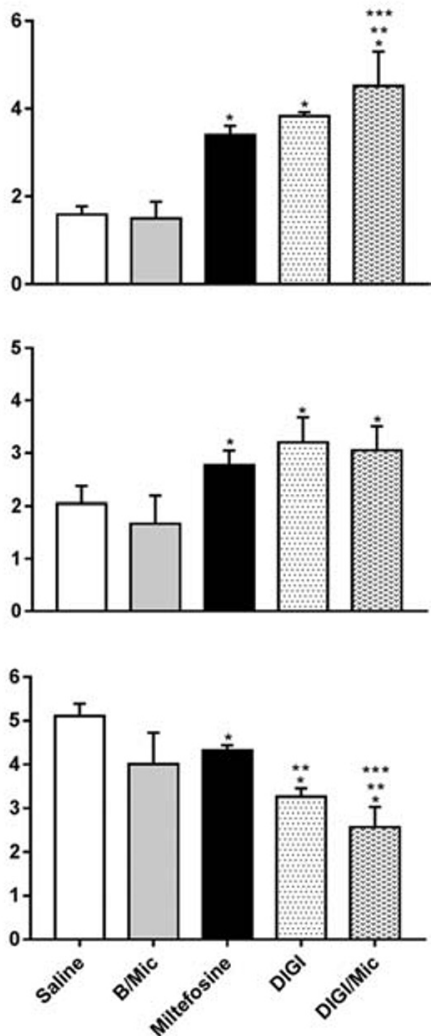

percentages in the SLA-stimulated versus unstimulated (control) cultures. Bars indicate the mean plus standard deviation of the groups. Single asterisk indicates a statistically significant difference in relation to the saline and $\mathrm{B} / \mathrm{Mic}$ groups $(P<0.05)$. Double asterisks indicate a statistically significant difference in relation to the miltefosine group ( $P$ $<0.05)$. Triple asterisks indicate a statistically significant difference in relation to the DIGI group $(P<0.05)$

higher therapeutic efficacy when associated to polymeric micelles.

Polymeric micelles as delivery systems present characteristics that make them suitable for administration via subcutaneous route. These polymers can create a semi-rigid gel when in contact with the local tissue where they were administered, turning them into a reservoir system which maintains the active agent within the extracellular space (Tavares et al. 2020). In the course of hours, the gel matrix dilutes and the drug are gradually released into the bloodstream, enabling its systemic action to be exerted in a controlled manner (Mendonça et al. 2019). These properties could allow reduced doses of the formulations to be administered at longer time intervals, thus reducing toxicity to the mammalian hosts, even with those drugs considered cardiotoxic, such as cardenolide derivatives. Therefore, future studies will need to be performed for a more comprehensive evaluation of DIGI as a VL-treating drug before its clinical application in other mammalian hosts, such as humans. 
Fig. 9 Parasite burden evaluation by limiting dilution technique. Mice were infected with L. infantum promastigotes and then administered with saline or were treated with empty micelles (B/Mic), miltefosine, DIGI, or DIGI/Mic. One and 15 days after treatment, their livers (a), spleens (b), draining lymph nodes (c), and bone marrows (d) were collected for determination of their parasite load by limiting dilution technique. Bars indicate the mean \pm standard deviation of the groups. Single asterisk indicates a statistically significant difference in relation to the saline and $\mathrm{B} / \mathrm{Mic}$ groups $(P<0.05)$. Double asterisks indicate a statistically significant difference in relation to the miltefosine group $(P<$ $0.05)$. Triple asterisks indicate a statistically significant difference in relation to the DIGI group $(P<$ $0.05)$
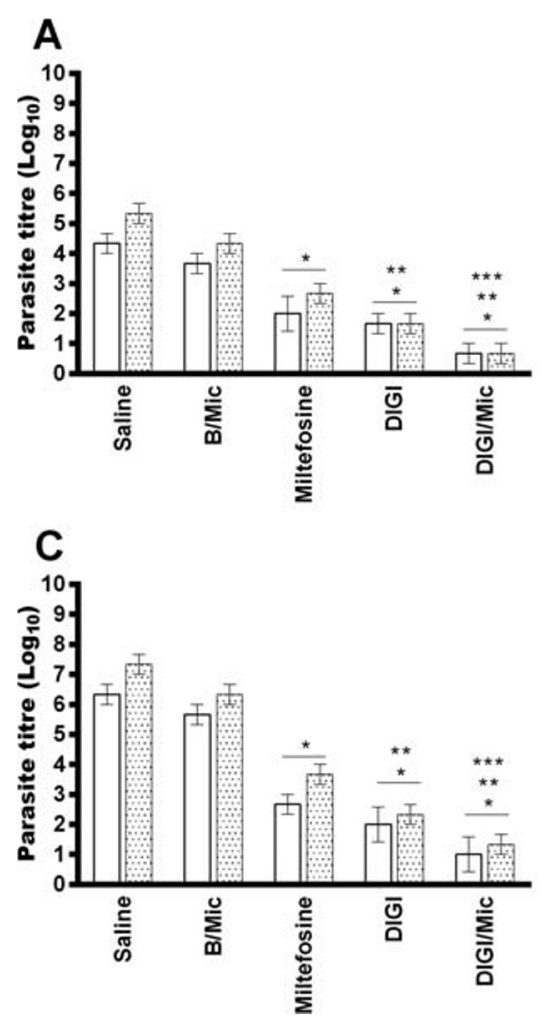

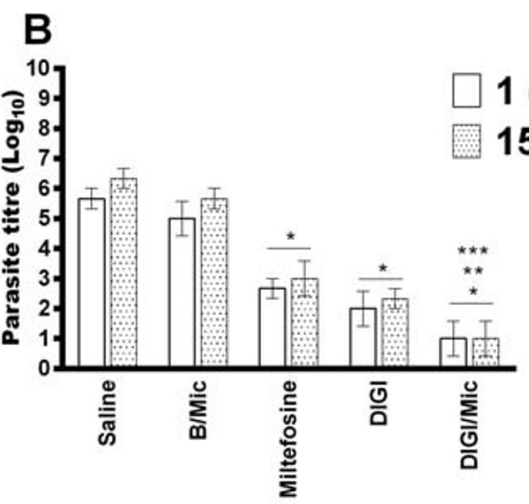

1 day 15 days

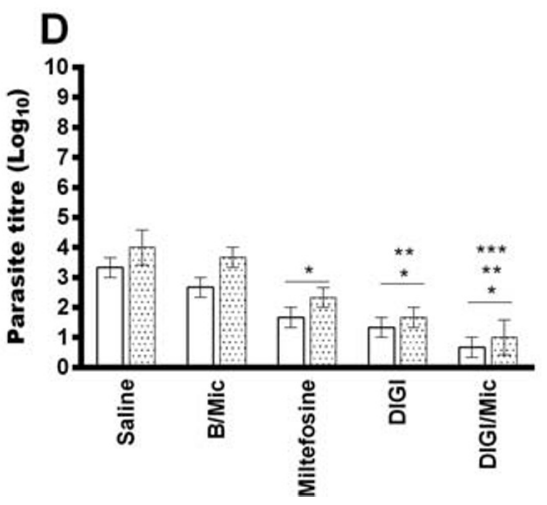

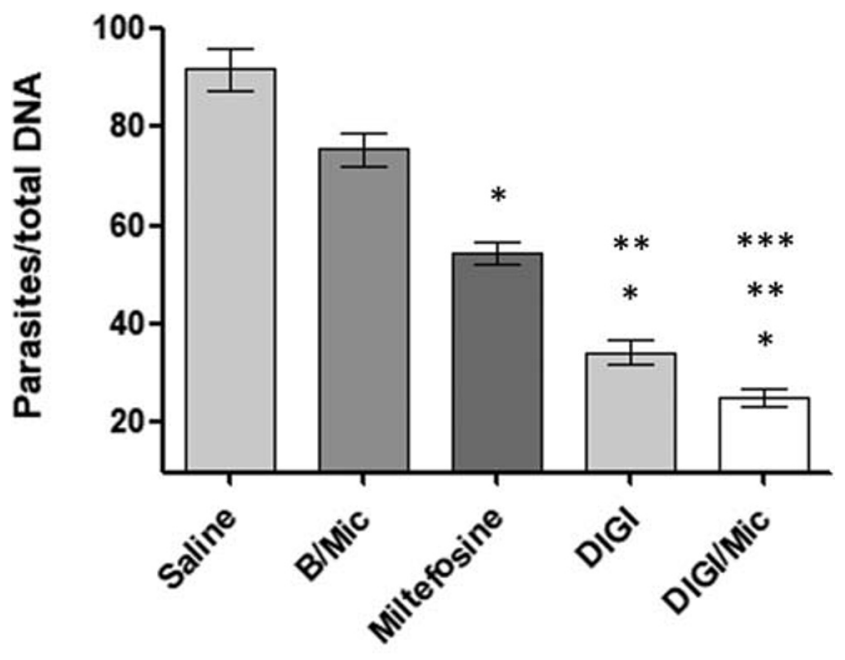

Groups

Fig. 10 Splenic parasite load evaluation by quantitative PCR (qPCR). L. infantum-infected BALB/c mice $(n=12$ per group) were treated 15 days post-treatment, animals ( $n=6$ per group) were euthanized, and their spleen collected and the parasite load were estimated by qPCR technique. Results were expressed as the number of parasites per total DNA. Bars indicate the mean \pm standard deviation of the groups. Single asterisk indicates a statistically significant difference in relation to the saline and $\mathrm{B} /$ Mic groups $(P<0.05)$. Double asterisks indicate a statistically significant difference in relation to the miltefosine group $(P<0.05)$. Triple asterisks indicate a statistically significant difference in relation to the DIGI group $(P<0.05)$
$\mathrm{BALB} / \mathrm{c}$ mice usually develop a severe infection when a high number of stationary promastigotes, such as the infective inoculum employed here, is used and can result in the development of Th2-type immune response, susceptibility, and visceralization of the infection. In the present study, control group mice developed severe infection, with high parasite load in distinct organs, loss of body weight, and weakness. All animals remaining after this study were therefore sacrificed 15 days post-treatment, adhering to Ethical experimental procedures. Studies evaluating therapeutic agents against murine VL normally perform their analysis at a single time point after treatment (Craft et al. 2014; Raja et al. 2017; Want et al. 2017; Valle et al. 2019). In our study, however, we performed immunological and parasitological evaluations 1 and 15 days after therapy. Nevertheless, a dose-response analysis with an increasing dosage or prolonged exposure to DIGI could determine in a more precise manner the therapeutic efficacy of this cardenolide derivate for treating VL. We are aware that this is a limitation of the work, and thus, additional experiments would be certainly required to fully characterize DIGI as an antileishmanial agent. Nevertheless, data presented here describe for the first time the antileishmanial activity of DIGI both in vitro and in vivo, with promising results suggesting that DIGI/Mic is worth considering in further evaluations for VL treatment. 
Acknowledgments The authors would like to thank Professor Wolfgang Kreis (Universität Erlangen-Nürnberg - Germany) for kindly providing the methanolic extract of Digitalis lanata. The authors also thank the Brazilian agencies Coordenação de Aperfeiçoamento de Pessoal de Nível Superior (CAPES), CNPq, and the Fundação de Amparo à Pesquisa do Estado de Minas Gerais (FAPEMIG) for the student scholarships.

Funding This work was supported by grant MR/R005850/1 from the Medical Research Council (VAccine deveLopment for complex Intracellular neglecteD pAThogEns-VALIDATE), UK, and grant APQ-408675/2018-7 from the Conselho Nacional de Desenvolvimento Científico e Tecnológico (CNPq), Brazil.

\section{Compliance with ethical standards}

Conflict of interest The authors declare that they have no conflicts of interest.

\section{References}

Adem E, Tajebe F, Getahun M, Kiflie A, Diro E, Hailu A, Shkedy Z, Mengesha B, Mulaw T, Atnafu S, Deressa T, Mathewos B, Abate E, Modolell M, Munder M, Müller I, Takele Y, Kropf P (2016) Successful treatment of human visceral leishmaniasis restores antigen specific IFN- $\gamma$, but not IL-10 production. PLoS Negl Trop Dis 10:e004468

Andrade-Neto VV, Cunha-Junior EF, Faioes VS, Pereira TM, Silva RL, Leon LL, Torres-Santos EC (2018) Leishmaniasis treatment: update of possibilities for drug repurposing. Front Biosci 23:967-996

Antonia AL, Wang L, Ko DC (2018) A real-time PCR assay for quantification of parasite burden in murine models of leishmaniasis 6 : e5905. https://doi.org/10.7717/peerj.5905

Arbabian H, Lee HM, Graudins A (2018) Elderly patients with suspected chronic digoxin toxicity: a comparison of clinical characteristics of patients receiving and not receiving digoxin-Fab. Emerg Med Australas 30:242-248

Biteker M, Özlek B, Özlek E, Biteker FS, Başaran N, Çekiç EG (2017) Digoxin use in atrial fibrillation. Am J Emerg Med 35:1196

Bruni N, Stella B, Giraudo L, Pepa CD, Gastaldi D, Dosio F (2017) Nanostructured delivery systems with improved leishmanicidal activity: a critical review. Int J Nanomedicine 12:5289-5311

Burza S, Croft SL, Boelaert M (2018) Leishmaniasis. Lancet 392:951970

Campbell TJ, Mc Donald PS (2003) Digoxin in heart failure and cardiac arrhythmias. Med J Aust 179:98-102

Chakravarty J, Sundar S (2019) Current and emerging medications for the treatment of leishmaniasis. Expert Opin Pharmacother 20:12511265

Chan EW, Wong SK, Chan HT (2016) Apocynaceae species with antiproliferative and/or antiplasmodial properties: a review of ten genera. J Integr Med 14:269-284

Coelho EAF, Tavares CA, Carvalho FA, Chaves KF, Teixeira KN, Rodrigues RC, Charest H, Matlashewski G, Gazzinelli RT, Fernandes AP (2003) Immune responses induced by the Leishmania (Leishmania) donovani A2 antigen, but not by the LACK antigen, are protective against experimental Leishmania (Leishmania) amazonensis infection. Infect Immun 71:3988-3994

Craft N, Birnbaum R, Quanquin N, Erfe MC, Quant C, Haskell J, Bruhn KW (2014) Topical resiquimod protects against visceral infection with Leishmania infantum chagasi in mice. Clin Vaccine Immunol 21:1314-1322
Dayakar A, Chandrasekaran S, Kuchipudi SV, Kalangi SK (2019) Cytokines: key determinants of resistance or disease progression in visceral leishmaniasis: opportunities for novel diagnostics and immunotherapy. Front Immunol 10:670

Dorlo TP, Balasegaran M, Beijnen JH, Vries PJ (2012) Miltefosine: a review of its pharmacology and therapeutic efficacy in the treatment of leishmaniasis. J Antimicrob Chemother 67:2576-2597

Duarte MC, Lage LM, Lage DP, Martins VT, Carvalho AM, Roatt BM, Menezes-Souza D, Tavares CA, Alves RJ, Barichello JM, Coelho EA (2016) Treatment of murine visceral leishmaniasis using an 8hydroxyquinoline-containing polymeric micelle system. Parasitol Int 65:728-736

Eid SY, El-Readi MZ, Wink M (2012) Digitonin synergistically enhances the cytotoxicity of plant secondary metabolites in cancer cells. Phytomedicine 19:1307-1314

Gheorghiade M, Harinstein ME, Filippatos GS (2009) Digoxin for the treatment of chronic and acute heart failure syndromes. Acute Card Care 11:83-87

Grimaldi G Jr, Tesh RB (1993) Leishmaniases of the New World: current concepts and implications for future research. Clin Microbiol Rev 6: 230-250

Gurel E, Karvar S, Yucesan B, Eker I, Sameeullah M (2017) An overview of cardenolides in digitalis - more than a cardiotonic compound. Curr Pharm Des 23:5104-5114

Hauptman PJ, Blume SW, Lewis EF, Ward SJACC (2016) Digoxin toxicity and use of digoxin immune Fab: insights from a national hospital database. Heart Fail 4:357-364

Hughes JP, Rees SS, Kalindjian SB, Philpott KL (2011) Principles of early drug discovery. Br J Pharmacol 162:1239-1249

Jamal F, Shivam P, Kumari S, Singh MK, Sardar AH, Pushpanjali MS, Narayan S, Gupta AK, Pandey K, Das VNR, Ali V, Bimal S, Das P, Singh SK (2017) Identification of Leishmania donovani antigen in circulating immune complexes of visceral leishmaniasis subjects for diagnosis. PLoS One 12:e182474

Kaye PM, Svensson M, Ato M, Maroof A, Polley R, Stager S, Zubairi S, Engwerda CR (2004) The immunopathology of experimental visceral leishmaniasis. Immunol Rev 201:239-253

Kedzierski L, Evans KJ (2014) Immune responses during cutaneous and visceral leishmaniasis. Parasitology 30:1-19

Mendonça DVC, Lage DP, Calixto SL, Ottoni FM, Tavares GSV, Ludolf F, Chávez-Fumagalli MA, Schneider MS, Duarte MC, Tavares CAP, Alves RJ, Coimbra ES, Coelho EAF (2018) Antileishmanial activity of a naphthoquinone derivate against promastigote and amastigote stages of Leishmania infantum and Leishmania amazonensis and its mechanism of action against L. amazonensis species. Parasitol Res 117:391-403

Mendonça DVC, Tavares GSV, Lage DP, Soyer TG, Carvalho LM, Dias DS, Ribeiro PAF, Ottoni FM, Antinarelli LMR, Vale DL, Ludolf F, Duarte MC, Coimbra ES, Chávez-Fumagalli MA, Roatt BM, Menezes-Souza D, Barichello JM, Alves RJ, Coelho EAF (2019) In vivo antileishmanial efficacy of a naphthoquinone derivate incorporated into a Pluronic ${ }^{\circledR}$ F127-based polymeric micelle system against Leishmania amazonensis infection. Biom Pharmacol 109: 779-787

Mijatovic T, Kiss R (2013) Cardiotonic steroids-mediated Na+/K+ATPase targeting could circumvent various chemoresistance pathways. Planta Med 79:189-198

Mohamed-Ahmed AH, Brocchini S, Croft SL (2012) Recent advances in development of amphotericin B formulations for the treatment of visceral leishmaniasis. Curr Opin Infect Dis 25:695-702

Oliveira-de-Siqueira LB, Cardoso VS, Rodrigues IA, Vazquez-Villa AL, Santos EP, Guimarães BCLR, Coutinho CSC, Vermelho AB, Junior ER (2017) Development and evaluation of zinc phthalocyanine nanoemulsions for use in photodynamic therapy for Leishmania spp. Nanotechnology 28:065101 
Pádua RM, Oliveira AB, Souza-Filho JD, Vieira GJ, Takahashi JA, Braga FC (2005) Biotransformation of digitoxigenin by Fusarium ciliatum. J Braz Chem Soc 16:614-619

Patel CN, Kumar SP, Modi KM, Soni MN, Modi NR, Pandya HÁ (2019) Cardiotonic steroids as potential $\mathrm{Na}(+) / \mathrm{K}(+)$-ATPase inhibitors - a computational study. J Recept Signal Transduct Res 39:226-234

Raja MRC, Velappan AB, Chellappan D, Debnath J, Kar Mahapatra S (2017) Eugenol derived immunomodulatory molecules against visceral leishmaniasis. Eur J Med Chem 139:503-518

Rijal S, Ostyn B, Uranw S, Rai K, Bhattarai NR, Dorlo T, Beijnen JH, Vanaerschot M, Decuypere S, Dhakal SS, Das ML, Karki P, Singh R, Boelaert M, Dujardin JC (2013) Increasing failure of miltefosine in the treatment of Kala-azar in Nepal and the potential role of parasite drug resistance, reinfection, or noncompliance. Clin Infect Dis 56:1530-1538

Sakkas H, Gartzonika C, Levidiotou S (2016) Laboratory diagnosis of human visceral leishmaniasis. J Vector Borne Dis 53:8-16

Scalese MJ, Salvatore DJ (2017) Role of digoxin in atrial fibrillation. J Pharm Pract 30:434-440

Singh OP, Stober CB, Singh AK, Blackwell JM, Sundar S (2012) Cytokine responses to novel antigens in an Indian population living in an area endemic for visceral leishmaniasis. PLoS Negl Trop Dis 6:e1874

Singh PK, Pawar VK, Jaiswal AK, Singh Y, Srikanth CH, Chaurasia M, Bora HK, Raval K, Meher JG, Gayen JR, Dube A, Chourasia MK (2017) Chitosan coated Pluronic F127 micelles for effective delivery of amphotericin B in experimental visceral leishmaniasis. Int J Biol Macromol 105:1220-1231

Slingerland M, Cerella C, Guchelaar HJ, Diederich M, Gelderblom H (2013) Cardiac glycosides in cancer therapy: from preclinical investigations towards clinical trials. Investig New Drugs 31:1087-1094

Sousa JKT, Antinarelli LMR, Mendonça DVC, Lage DP, Tavares GSV, Dias DS, Ribeiro PAF, Ludolf F, Coelho VTS, Oliveira-da-Silva JA, Perin L, Oliveira BA, Alvarenga DF, Chávez-Fumagalli MA, Brandão GC, Nobre V, Pereira GR, Coimbra ES, Coelho EAF (2019) A chloroquinoline derivate presents effective in vitro and in vivo antileishmanial activity against Leishmania species that cause tegumentary and visceral leishmaniasis. Parasitol Int 73: 101966

Srivastava S, Mishra J, Gupta AK, Singh A, Shankar P, Singh S (2017) Laboratory confirmed miltefosine resistant cases of visceral leishmaniasis from India. Parasit Vectors 10:49

Su LJ, Zhang JH, Gomez H, Murugan R, Hong X, Xu D, Jiang F, Peng ZY (2019) Reactive oxygen species-induced lipid peroxidation in apoptosis, autophagy, and ferroptosis. Oxidative Med Cell Longev 2019:5080843

Sundar S, Chakravarty J (2015) Investigational drugs for visceral leishmaniasis. Expert Opin Investig Drugs 24:43-59
Sundar S, Singh A (2018) Chemotherapeutics of visceral leishmaniasis: present and future developments. Parasitology 145:481-489

Sundar S, Singh A, Agrawal N, Chakravarty J (2019) Effectiveness of single-dose liposomal amphotericin B in visceral leishmaniasis in Bihar. Am J Trop Med Hyg 101:795-798

Tavares GSV, Mendonça DVC, Lage DP, Granato JDT, Ottoni FM, Ludolf F, Chávez-Fumagalli MA, Duarte MC, Tavares CAP, Alves RJ, Coimbra ES, Coelho EAF (2018) Antileishmanial activity, cytotoxicity and mechanism of action of clioquinol against Leishmania infantum and Leishmania amazonensis species. Basic Clin Pharmacol Toxicol 123:236-246

Tavares GSV, Mendonça DVC, Pereira IAG, Oliveira-da-Silva JA, Ramos FF, Lage DP, Machado AS, Carvalho LM, Reis TAR, Perin L, Carvalho AMRS, Ottoni FM, Ludolf F, Freitas CS, Bandeira RS, Silva AM, Chávez-Fumagalli MA, Duarte MC, Menezes-Souza D, Alves RJ, Roatt BM, Coelho EAF (2020) A clioquinol-containing Pluronic ${ }^{\circledR}$ F127 polymeric micelle system is effective in the treatment of visceral leishmaniasis in a murine model. Parasite 27:29

Valle IV, Machado ME, Araújo CDCB, Cunha-Junior EF, Pacheco JS, Torres-Santos EC, Silva LCRP, Cabral LM, Carmo FA, Sathler PC (2019) Oral pentamidine-loaded poly(d,l-lactic-co-glycolic) acid nanoparticles: an alternative approach for leishmaniasis treatment. Nanotechnology. 30:455102

Van Griensven J, Diro E (2019) Visceral leishmaniasis: recent advances in diagnostics and treatment regimens. Infect Dis Clin N Am 33:7999

Wagner V, Minguez-Menendez A, Pena J, Fernández-Prada C (2019) Innovative solutions for the control of leishmaniases: nanoscale drug delivery systems. Curr Pharm Des 25:1582-1592

Want MY, Islammudin M, Chouhan G, Ozbak HA, Hemeg HA, Chattopadhyay AP, Afrin F (2017) Nanoliposomal artemisinin for the treatment of murine visceral leishmaniasis. Int J Nanomedicine $12: 2189-2204$

Whayne TF Jr (2018) Clinical use of digitalis: a state of the art review. Am J Cardiovasc Drugs 18:427-440

World Health Organization (2018) Leishmaniasis. http://www.who.int topics/leishmaniasis/en/, 2018, Accessed data: 2 June 2018

Xu J, Guo Y, Sui T, Wang Q, Zhang Y, Zhang R, Wang M, Guan S, Wang L (2017) Molecular mechanisms of antioxidant and antiaging effects induced by convallatoxin in Caenorhabditis elegans. Free Radic Res 51:529-544

Publisher's note Springer Nature remains neutral with regard to jurisdictional claims in published maps and institutional affiliations. 


\section{Affiliations}

Camila S. Freitas ${ }^{1}$ - João A. Oliveira-da-Silva ${ }^{1} \cdot$ Daniela P. Lage $^{1} \cdot$ Rafaella R. Costa $^{1} \cdot$ Débora V. C. Mendonça $^{1} \cdot$ Vívian T. Martins ${ }^{1} \cdot$ Thiago A. R. Reis $^{1} \cdot$ Luciana M. R. Antinarelli $^{2} \cdot$ Amanda S. Machado $^{1} \cdot$ Grasiele S. V. Tavares $^{1}$ • Fernanda F. Ramos ${ }^{1} \cdot$ Vinicio T. S. Coelho ${ }^{1} \cdot$ Rory C. F. Brito ${ }^{3} \cdot$ Fernanda Ludolf $^{1} \cdot$ Miguel A. Chávez-Fumagalli $^{4}$. Bruno M. Roatt ${ }^{3}$. Gabriela S. Ramos ${ }^{5}$. Jennifer Munkert ${ }^{6}$. Flaviano M. Ottoni ${ }^{5}$ • Priscilla R. V. Campana ${ }^{5}$. Maria V. Humbert ${ }^{7}$ Elaine S. Coimbra ${ }^{2} \cdot$ Fernão C. Braga $^{5} \cdot$ Rodrigo M. Pádua $^{5} \cdot$ Eduardo A. F. Coelho $^{1,8} \mathbb{C D}^{\circ}$

1 Programa de Pós-Graduação em Ciências da Saúde: Infectologia e Medicina Tropical, Faculdade de Medicina, Universidade Federal de Minas Gerais, Belo Horizonte, Minas Gerais, Brazil

2 Departamento de Parasitologia, Microbiologia e Imunologia, Instituto de Ciências Biológicas, Universidade Federal de Juiz de Fora, Juiz de Fora, Minas Gerais, Brazil

3 Laboratório de Imunopatologia, Núcleo de Pesquisas em Ciências Biológicas, Departamento de Ciências Biológicas, Insituto de Ciências Exatas e Biológicas, Universidade Federal de Ouro Preto, Ouro Preto, Minas Gerais, Brazil

4 Universidad Católica de Santa María, Urb. San José S/N, Umacollo, Arequipa, Peru
5 Departamento de Produtos Farmacêuticos, Faculdade de Farmácia, Universidade Federal de Minas Gerais, Belo Horizonte, Minas Gerais, Brazil

6 Departament Biologie, LS Pharmazeutische Biologie, Universität Erlangen-Nürnberg, Erlangen, Germany

7 Neisseria Research Group, Molecular Microbiology, School of Clinical and Experimental Sciences, University of Southampton Faculty of Medicine, Southampton General Hospital, Southampton SO16 6YD, UK

8 Departamento de Patologia Clínica, COLTEC, Universidade Federal de Minas Gerais, Avenida Antônio Carlos, 6627 Campus Pampulha, Belo Horizonte, Minas Gerais 30130-100, Brazil 